\title{
Lobato e a Metafísica dos Personagens
}

Cesar Kiraly

\author{
Cesar Kiraly \\ Cesar Kiraly é professor de Teoria Política e Pensamento Social \\ Brasileiro no Departamento de Ciência Política da Universidade \\ Federal Fluminense. Coordenador Executivo do Laboratório de \\ Estudos Hum(e)anos. Editor das Revistas Estudos Políticos e \\ Estudos Hum(e)anos. Autor dos livros Os Limites da \\ Representação e O Guarda-Chuva de Regras. \\ Email: ckiraly@id.uff.br \\ ORCID: https://orcid.org/0000-0001-9593-0814
}

\section{Resumo}

Neste artigo investigo a primeira publicação de Lobato. N'O Saci-Pererê: resultado de um inquérito tento perceber elementos do que poderia ser denominado de uma metafísica política do personagem.

\section{Palavras-Chave}

Lobato, Saci, Metafísica Política do Personagem

\begin{abstract}
In this present article I inquiry the first publication of Lobato. Analyzing O Saci-Pererê: resultado de um inquérito I try to see the elements of what could be denominated a political metaphysics of the character.
\end{abstract}

\section{Key-Words}

Lobato, Saci, Political Metaphysics of the Character

Neste artigo investigo a primeira publicação de Lobato. N'O Saci-Pererê: resultado de um inquérito tento perceber elementos do que poderia ser denominado de uma metafísica política do personagem, em diálogo com o pensamento do Freud. 0 contexto da pesquisa concerne à interpelação psicanalítica do pensamento brasileiro, em especial em sua dimensão política. Poderíamos dizer que o pensamento brasileiro teve e tem estreita relação com o tema da transformação social, em seus muitos matizes. O pensamento do Lobato parece estar no cruzamento de uma possível viragem. Ele claramente pensa questões atinentes à transformação, mas também demonstra desconforto com o que seria uma modernidade brasileira. Quero com esse texto indicar o início de uma pesquisa de uma linha intimista no modo de pensar o Brasil, que ligará realizações distintas tais como as de certo pensamento do Lobato, Mario Peixoto, Lúcio Cardoso, Cornélio Penna e Mario Pedrosa. A intuição é que disponibilizam uma forma de pensar a crueldade que pode ser lida psicanaliticamente e 
que suspende a velha forma de com ela lidar pelo encobrimento , isso é, apenas pela alteração substantiva de um estado de coisas. A metafísica do personagem do Lobato é a contribuição que esta dá para tal forma de pensar. O modo teórico da leitura empreendida é concernente ao ceticismo filosófico.

\section{Introdução}

Este ensaio sobre parte da obra de Lobato começa com interpelação do conceito de personagem. Julgamos que essa é a entrada nobre, o início íntimo, por assim dizer, no que concerne à expressão política de sua obra. Antes de tudo existe um problema lógico na obra dos grandes pensadores - insinuo que trataremos de um -, a estrutura que mobilizam nunca é completamente redutível, sempre algo resta misterioso. Na sua obra existe esse algo de estrutura, um componente irredutível, que de alguma forma o liberta, em parte, de sua biografia, e do esforço da narrativa historiográfica de encerrá-lo em seu tempo. Para tratar dos possíveis efeitos políticoconceituais de sua obra, a história pode pouco ou quase nada, posto que ele será visto como um autor, melhor do que isso, como alguém que detém um pensamento.

A preocupação com a possibilidade política da obra de Lobato, com razão, distingue-se de uma aproximação despreocupada, marcadora de sua recepção como escritor de entretenimento de crianças inteligentes e de adultos leitores de jornal, num dos lados da moeda, e da recepção de sua obra como esclarecedora de certo estado de coisas que vai da campanha civilista até a década de 30 . Ainda que sua obra não seja estritamente conceitual, parece que a aproximação preocupada poderá tirar conceitos dela. É isso que queremos com a idéia de metafísica dos personagens.

Pois bem, um Lobato capaz de preocupar - pensando "estar preocupado" como uma paixão filosófica - demanda alguma concessão, alguns comprometimentos morais de sua obra não serão trabalhados, mas nos aproveitaremos da densa desarrumação provocada pelo horizonte de conceitos. Lobato é um homem de negócios, um escritor, um crítico, um artista plástico e metido a dar pitacos sobre coisas que não realmente entende. Mas longe de tornar a sua obra desinteressante, essa aparente esquizofrenia de seus enunciados, ajuda-nos a não diminuí-lo sob tentações inteligentes. A historiografia, aqui, servir-nos-á para não permitir Lobato dizer menos, mas nunca será tomada como limite do "até onde" ele pode dizer.

O limite negativo será dado pela historiografia, mas jamais o positivo, pelo evitamento da mordaça, o acompanhamento dos escritos para adultos, muitos vinculados a trabalhos na imprensa de São Paulo e a tomadas de posição, serão utilizados como fio condutor. Mais especificamente a linha narrativa de confecção da investigação sobre o Saci. Ainda que a obra dele como um todo nos interesse, e que possamos defender que a lógica de leitura que empreenderemos pode ser continuada, julgamos que o princípio da metafísica dos personagens será mais bem aproveitado se formos capazes de mostrar o procedimento de montagem sobre os relatos.

Não é difícil perceber a presença de personagens no corpus lobatiano, de uma forma um pouco exagerada, poderíamos dizer que criar personagens foi a sua atividade de vida, além de certo esforço de promoção de situações dramatúrgicas. Mas não é bem claro ver o modo pelo qual a produção de personagens poderia se ligar a uma metafísica. Além do que deverá restar demonstrado quais são os elementos políticos dessa metafísica. O que seria, pois, uma metafísica dos personagens? 
Antes de respondermos a essa crucial questão, e para respondê-la, devemos colocar o problema do ambiente dramatúrgico em que os personagens são criados. A dramaturgia é o ambiente de sustentação dos personagens, por assim dizer, eles atuam, ou agem, e nela, seguem as suas finalidades. Dessa forma, um personagem não possui uma finalidade tout court, este é um privilégio dramatúrgico, mas aquela que lhe foi conferida em seus limites de sustentação. O horizonte do personagem é um horizonte de segunda linha. E os personagens usados por Lobato não são propriamente conceituais, ainda que desejemos extrair efeitos conceitos em função da estrutura da leitura que propomos. Assim, ainda que exista algo de uma afinidade idealista no modo pelo qual Lobato faz com que seus personagens falem, cabe lembrar que ele não é um filósofo, e isso o salva das conseqüências soberanas.

Assim, ao mesmo tempo em que a dramaturgia é a ficção do personagem, de modo a não poder questioná-la, não poder genuinamente negociar, ela é o ser e a metafísica do personagem.

A metafísica do personagem, numa dramaturgia convencional, é algo que podemos chamar de uma dramaturgia soberana; nela o personagem é levado a falar para representar algo que excede a sua metafísica, mas que a ela é coerente, ou seja, ele representa a voz do autor. A metafísica do personagem em sua acepção soberana, que não é o caso da obra de Lobato, é encontrável apenas em literatura de baixíssima qualidade ou na teoria política, em seus sentidos mais convencionais. Trata-se de um exercício um tanto quanto vulgar da ficção. O uso da ficção como o modo de apresentação do mundo que "eu" desejo ou dos meus enunciados. Mas um axioma podemos retirar da metafísica do personagem, inclusive na sua acepção soberana, nela sempre se fala pela boca de outrem, a enunciação representa algo que se faz opaco. Alguém presente fala no lugar de alguém um pouco ausente.

Assim, respondendo a pergunta posta, a metafísica do personagem é modalidade de representação, inclusive da política, que se estrutura sobre um plano dramatúrgico, ao invés de um plano pictórico, de autoria clara ou difusa, cuja forma mais radical é a soberana, segundo a qual o enunciado representa o infinito de um enunciador infinito. A dramaturgia soberana é muito útil à política tradicional, mas muito vulgar à literatura. Não é difícil quebrar as pernas de um autor com desejo de multiplicação infinita no tempo, mas é sempre difícil quebrar as pernas de Deus, da soberania popular ou de uma comunidade organizada falando pelos costumes, e manutenção de formas de vida. Cabe-nos agora perceber a natureza da dramaturgia lobatiana. Além do que mostrar que a sua plasticidade não-política Ihe permite efeitos de configuração de mundo bastante efetivos.

Lobato, como todo pensador, é um animal depravado. Contudo, a sua depravação não decorre da aceitação da representação soberana, como, por exemplo, ocorre na depravação de Rousseau, porque apenas com muita parvonice, no campo literário, pode-se aceitar que uma ou poucas pessoas, e suas vozes, representem muitas vozes ou uma voz infinita. O autor não se faz grande, porque soberano, mas porque finito. Assim, basta que sejamos um pouco depravados para vermos que seria tolice para um autor defender uma ficção soberana. Contudo, a história do pensamento político nada mais é do que a demografia de fracas ficções, salvo os melhores exemplos. Lobato não seria levado a crer em todo o pacote de ficções políticas soberanas - mas era facilmente persuadido por péssimas fábulas econômicas -, muito embora soubesse vê-las e percorrê-las.

Poderiam nos advertir que é evidente que a metafísica dos personagens de Lobato é muito mais fina do que a tradicional metafísica soberana dos personagens da 
filosofia política - com os seus homens devoradores de homens, bons selvagens, homens de clima frio propensos ao trabalho e homens de clima quente, propensos à obediência - posto ser Lobato um romancista e não estar adstrito as mesmas necessidades de autoridade e organização social de um filósofo. Mas a objeção não é inteiramente verdadeira, porque desejo mostrar que em Lobato a metafísica dos personagens possui efeitos políticos semi-conceituais, que, por sinal, são mais efetivos do que aqueles praticados por outros pensadores brasileiros, dentre outras razões, porque pensou sob o regime de uma metafísica política dos personagens. Ou seja, Lobato pensava em inserir num plano dramatúrgico, retoricamente, um novo personagem capaz de re-configurar, uma vez persuadindo os seus leitores, o sentido de práticas sócio-políticas, como, por exemplo, o lugar no negro, dentre outros fenômenos.

Assim, não existe uma metafísica soberana dos personagens em sua obra, mas algo muito mais fino. A metafísica dos personagens de Lobato funciona por contigüidade. Apenas para nos adiantarmos um pouco, podemos dizer que ela insere no campo da dramaturgia política um objeto que lhe é coerente, mas relativamente estranho, que obriga a recolocação dos personagens. A prática da metafísica política dos personagens de Lobato demanda, antes de tudo, uma extrema sensibilidade descritiva do tempo atual, mas não consiste numa descrição fiel, mas, sobretudo, uma descrição cruel, aparentemente muito pouco generosa com as fraquezas internas dos personagens descritos, depois, uma sorte de meditação cruel sobre os personagens encontrados, o vislumbramento de suas cores, enquanto compositivas de ficções. A metafísica dos personagens de Lobato não o é enquanto melhoramento puro e simples de um estado ficcional de coisas, mas, principalmente, na fraqueza ficcional desse estado de coisas, acrescentar-lhe um novo personagem terrível. A metafísica, nesse caso, é muito mais o desafio do que um diagnóstico, num certo sentido, é muito mais reinação do que generosidade política. Cabe, aqui, ser cruelmente verdadeiro para acrescentar ao estado de coisas uma ficção à altura dos ficcionistas.

A divisão estrutural que faremos em nossa leitura de Lobato, como dito, concebe, de um lado, as obras para adultos. Nessas teremos o exercício dessa descrição cruelmente verdadeira de um estado de coisas, esta não se confunde com uma descrição sociologicamente rigorosa - o que o salva de alguns excessos de contemporâneos mais "sérios", como Oliveira Viana -, mas ampliada pelo mau humor de quem sempre se sente fora do lugar. Do outro lado, as obras para crianças. Nessas teremos a imaginação dos personagens aflorada, até mesmo excessiva, mas absolutamente tendente a restar mesclada ao corpo da dramaturgia, cruelmente percebida.

A divisão entre os dois campos não é de nenhuma forma estanque, principalmente no início do corpus lobatiano. Pode-se encontrar material imagista na obra do Lobato adulto e uma bela crueldade descritiva nos romances para crianças. A criança e o adulto nada mais são do que estratégias enunciativas para a consolidação, em espectro, de uma potente metafísica sobre as antigas e fracas ficções. Não poderíamos deixar de optar por essa estrutura de personagens para tratar desse autor de personagens. Contudo, o mais relevante é que concedamos à obra para crianças a intensidade do anacronismo, ou seja, nela estarão os personagens, alguns até mesmo, por esforço da leitura, com os contornos de personagens conceituais e operadores de conceitos. A obra para adultos, por outro lado, conduzir-nos-á por alguma ordem temporal. Mas também não devemos ser muito rigorosos com isso, pois a relação poderá, por vezes, ser invertida. 
O problema, todavia, poderia ser descrito de outra forma. Imaginemos então que a política pode ser reduzida a seus elementos mínimos. Digamos que tal procedimento se justifique, posto que se julgamos que a política está em todos os lugares, pode ser que algo relevante no seu processo de fixação se torne indeterminável, e que se tal acontecimento se dá, pode ser que, se há vício na experiência política, ele não seja percebido, o que seria bastante ruim. A este procedimento, julgamos, poderíamos dar a denominação de determinação da ontologia política, uma vez que perceberia o mínimo para que uma experiência possa ser denominada política, por assim dizer, notaria o seu ser, ou, no caso em questão, a sua melhor aparência. Claro seria que uma tal ontologia política não poderia bem dizer o que a política é, posto que o procedimento de visada entregaria rapidamente que a política é em certas circunstâncias, podendo ser denominada muito mais matéria de quando do que de ser. Nisso não se diz que a política é mas que quando ela é a crueldade está envolvida. Por essa razão parece ser o discurso cético o mais apropriado para a investigação da política, porque quem diz o quando diz a aparência e é sobre essa que os céticos se debruçam. Mas a preocupação com a crueldade também é intensidade mobilizada pelo ceticismo, pelo menos desde o seu mais expressivo ressurgimento com Montaigne, Bayle e Hume. Claro se torna a boa recepção que o ceticismo pode dar à tradição psicanalítica.

Dessa forma, como dissemos, a pergunta de uma ontologia política não seria 0 que é a política, mas quando é a política. A hipótese que liga este tipo de questão à psicanálise é que parte da resposta dirá que a política é quando alguém restringe algo a outrem por certo espaço de tempo. Este mecanismo tem que ver com a causação da dor, donde o seu explícito aspecto vicioso, e o início de uma série de problemas acerca da ambivalência da experiência política. Aqui é que o problema da dramaturgia se inicia. Porque existem esquivas à percepção direta da crueldade, que, de modo previsível permitem o seu aprofundamento. A dramaturgia pode ser remetida ao tema da representação e da representação política.

A dramaturgia, grosso modo, ocorreria tal como em certos modos de descrição do pensamento e tal como na representação política, a saber, quando alguém falasse no lugar de outrem. As analogias aqui não são acidentais, em planos diferentes, a representação, ou dramaturgia, oferece um modo de compreender e agir que se dá pela suplência, positiva ou negativa. As razões dadas do porquê isso acontece são as mais variadas, no campo cognitivo a afirmativa é uma certa dualidade entre 0 pensamento e o mundo, de tal forma que o pensamento não imagina o mundo mesmo, mas uma cópia deste, obtida a partir dos órgãos de sentido. No campo da representação política as explicações costumam ser demográficas, ela se daria nos seguintes termos: porque existem muitas pessoas no mundo, e a prática política tem que ver com fazer coisas, é preciso que alguns representem muitos, quão mais ampla a representação, melhor seria, mas sem limitação de atores não se poderia realizar nada. O primeiro intento é pensar em termos numéricos, se um grande número representa um grande número, então é como se as pessoas quase representassem a si próprias, mas é claro que os mesmos problemas seriam recolocados, de tal forma que é possível se julgar que um pequeno número pode representar bem um grande número se o fizer de acordo com os valores dessas pessoas, donde elas seriam bem representadas. Há deformações de toda forma no tema da representação política, uma delas é a da tutela, de forma que em certos momentos poucos saberiam o que é melhor para muitos, por diversas razões, donde representariam o grande número de um modo melhor à maneira pela qual este mesmo número compreende que deve ser representado. Assim, para o nosso argumento, não é importante dizer o que é a 
dramaturgia no sentido cultural, porque ela pode ser muita coisa, e também não é bem o caso de dizer por que representamos, porque as mais variadas explicações podem ser dadas. Mas o que queremos indicar é que representamos e que na representação produzimos uma espécie de teologia política. Ora, se representamos, falamos por, e ao falarmos por estabelecemos desníveis verticais entre quem dramatiza e a experiência dramatizada, tal acaba por constituir modos de autoridade.

Queremos dizer que essa forma de proceder é bastante imoral, justamente porque encobre a crueldade. Os modos dramatúrgicos nos distraem do fato de que a viabilidade da estabilização dos modos da humanidade no tempo dependem da crueldade, e por isso mesmo essa deve ser vista para ser mantida em seus níveis mínimos. A física que julgamos identificar pode nos levar a dizer que a dramaturgia ao encobrir a crueldade a aprofunda.

Lobato, como não poderia deixar de ser, como filho de um meio, move-se por tal dramaturgia política. Ela pode ser percebida em toda sorte dos seus delírios de grandeza nacional. Desde a idéia da necessidade do desenvolvimento industrial angloamericano no Brasil, em centelhas já existentes no Barão de Mauá, por exemplo, até a intuição de que existiria petróleo em território nacional e que sua exploração rumo à formas de independência deveria partir da iniciativa privada, um dos motivos pelo qual foi preso nos anos da era Vargas. Mas se fosse apenas isso a obra do Lobato, o seu interesse seria apenas histórico, há nele também um órfão. Acreditamos que por um lado Lobato se embrenha nos matagais das formas de teologia política, em concepções tão triviais quanto a necessidade de uma transformação nacional até idéias bem mais graves. Mas também vemos que ele vai muito mais longe do que isso. Uma das formas pelas quais ele o faz é justamente o que denominamos aqui de uma metafísica política dos personagens. Ele imagina operadores literários que interrompem o ciclo dramatúrgico e tornam a crueldade explícita. O seu esforço, todavia, não pode nunca ser completo, porque, por operar por personagens, já realiza ele mesmo um movimento de encobrimento. Mas, como dito acima, cremos que essa tradução intimista foi aprofundada no pensamento brasileiro, e a obra do Lobato poderia ser tomada como uma espécie de marco zero desta modernidade intimista, a despeito mesmo de sua larga histrionia política.

É por essa razão que o tema da crença deve ser trazido ao proscénio. Porque todos sabemos que a sociabilidade depende das crenças para se estruturar, mas é a tradição cética que após descrever o processo da crença consegue nos oferecer uma forma para compreendê-la em seu processo de fixação. É na crença, em última instância, que se pode buscar a percepção da crueldade.

\section{Inquérito e estrutura da imagem}

A primeira obra de Lobato, que podemos incluir em seus trabalhos para adultos, foi o resultado de um inquérito. Ele publica artigos, que depois estariam no livro Urupês, alguns bastante polêmicos, no jornal O Estado de São Paulo e na Revista do Brasil. N'O Estado de São Paulo provoca seus leitores a remeterem suas impressões sobre o Saci. A idéia de Lobato é criar uma colcha de retalhos com várias representações distintas, realizar, acerca dessa crença do interior de São Paulo, um experimento de confluência diaphônica. Ao invés de evitar a pluralidade dos discursos apelando aos homens de letras e de ciência, prefere dissolver a diferença entre experimento e experiência e ouvir a todos. Inclusive, dando oportunidade para que a própria crença fale-de-si. A crença também encontra abrigo na boataria.

Estranhamente o inquérito do Saci também é um esforço de guerra. Ele, o inquérito, aparece pela primeira vez em 1917, sob o título de Mitologia Brasílica. A 
segunda aparição do texto, em 1918, foi também impressa pela gráfica d'O Estado de São Paulo (digno de nota são os divertidos anúncios comerciais, veiculados para ajudar no financiamento da publicação, de autoria do ilustrador e caricaturista Lemmo Lemmi). Assim, trata-se de um texto provocado, escrito e publicado no decurso da guerra de 1914.

O Çaa Cy Perereg (ou "o olho mal que saltita"), para Lobato, só pode ser visto a partir da diaphonia do interior de São Paulo (algo de Minas e Rio) e esta é reativa à "carniçaria européia". À Carniçaria européia deve ser oposta uma prática de investigação que evite, tal como na carniçaria "[...] que um só sujeito tome conta ao assunto e imponha maçadamente a sua idéia em estiradas considerações eruditas $[\ldots]$..i. O Inquérito é mais razoável do que a autoridade, porque nele "[...] todos falam, o estilo varia, o pitoresco aumenta; e concorrem sobretudo os não-profissionais das letras ${ }^{\mathrm{iii \prime}}$. Lobato, por certo, tem uma concepção bem interessante de inquérito, até mesmo incorreta, o que apenas a torna mais interessante. Para ele o inquérito é, acredito que só nesse caso em particular, ou num número de específicos objetos da imaginação, uma atividade que investiga um mal divertido - porque saltitante -, ou consiste numa forma de olho que busca um outro olho; mas que é, sobretudo, passiva, a não ser na manifestação do interesse. Por certo que é um inquérito não-carniceiro ao contrário do que se vê no Édipo ou nas formas inquisitoriais, sempre ativas.

Este inquérito lobatiano é bastante não-edipiano, pois o Édipo é o olho do mal que busca a si próprio, e, no que se encontra, cega-se aos furos por ser o olho do mal e vaga pelo deserto. No inquérito lobatiano, o olho perscrutador não busca, mas enuncia a busca para que se lhe venham os olhos, o olho lobatiano busca um outro olho, um que diferente de si, saltite, e que ao saltar, seja mau. Ainda que o livro do inquérito "[r]evele o onde e o como se há de buscar os elementos de estudo e compreensão de nós próprios", o livro, por si mesmo, busca o Saci. E esta simplicidade é deveras importante, porque é um mal simples e pouco ambivalente que nos faz perdoar o Saci quando comparado à carniçaria européia. O Saci não é a ausência do mal, mas um outro mal. Aparentemente, preferível.
Por várias semanas alvorotaste meio mundo, oh infernal maroto, e desviaste a nossa atenção para quadro mais ameno que o trucidar dos povos. Bendito seja! Estás perdoado de muitas travessuras por haveres interrompido, por um momento, em nossa imaginação, a hedionda sessão permanente de horror, aberta pelo sinistro 2 de Agosto de 1914, de execrabilíssima memóriaiv.

Mas por que o inquérito lobatiano é tão distinto? Por um artifício de finalidade. Uma vez que o inquérito recolhe representações, como quem junta as peças de um sistema de crenças, a sua finalidade é uma imagem e seus elementos são pigmentos de composição. A imagem enquanto finalidade é um ardil contra a finalidade. Porque a imagem consegue ser figuração de algo apenas quando tem alguma outra diferente de si para operar como finalidade.

A imagem que tem, por exemplo, a mimesis como finalidade, consiste apenas numa imagem de segunda ordem, e, por isso, é capaz de ver a si mesma de modo estabilizado, uma vez que ignora a composição de si, e, no caso do exemplo, é distraída pela cópia. Mas esse não é o procedimento realizado por Lobato, ele afasta qualquer distração e se faz interessado pela finalidade imagem-Saci.

A diferença é que, sem distração, Lobato terá, e nos mostrará, apenas a figurabilidade do saci e nunca a sua completa figuração. Apenas vê o Saci, de uma 
única forma, aquele que está distraído, o atento se afoga na pluralidade de representações. O distraído, como ironicamente diz Lobato, com o Saci se afasta da guerra e absolve o pequeno olho do mal que saltita. $O$ atento, vê no Saci a guerra interna à sua imagem, a nossa guerra.

A imagem como finalidade, a única que mostra a sua composição, em sua figurabilidade mostra um núcleo de crença, o umbigo da crença, e, nas circularidades que se expandem, evidencia as regularidades opinativas.

\section{A densidade da imagem e a guerra}

Não é sem interesse que Freud publica o seu ensaio Considerações Atuais sobre a Guerra e a Morte no mesmo período. Se pensarmos em linhas bastante gerais, veremos que os espíritos do Inquérito e das Considerações se assemelham. Muitas podem ser as causas, alguma leitura Nietzsche, a qual os dois compartilhavam, ou um profundo ceticismo, talvez por uma feliz coincidência de temperamentos, sobre valores.

O ceticismo sobre valores é distinto do sobre o conhecimento, aquele não tem especial interesse sobre a parcialidade da experiência. O ceticismo sobre valores, por isso, - e não é o caso de perguntar aqui às temáticas de epistemologia - consiste na percepção de que há algo de intrinsecamente problemático com as nossas estruturas sociais. Tanto em Freud, quanto em Lobato, é pela evidência da miserabilidade da civilização européia que o mal se tornou um sinônimo da morte.

O problema, nessa medida, não é a existência do mal em nossas sociedades, mas a radicalidade por ele tomada na guerra. Lobato parece crer na necessidade do mal, mais ainda, em sua sociabilidade lúdica, até mesmo em sua infantilização. O Saci encarna esse mal-doce. Ele reage, portanto, ao mal amargo da carniçaria da selvageria de modos civilizados.

Então, para justificarmos a visita a esse estranho inquérito, para além da leve e frívola admissão de que existe um componente selvagem em toda investida civilizacional, é necessário admitir que o monopólio sobre o mal imaginário não é desejável, porque leva a forma social da civilização a estado de carniçaria. Se a civilização é a forma total da sociabilidade - e ela, por alguma razão, persuade que não há o que temer, senão o próprio medo, que pode enfrentar todos os inimigos, de modo a inexistir a relevância aos pequenos medos e a crença na insuportabilidade dos grandes -, o que existe é uma sensação cotidiana de não-morte. Ainda que a civilização esteja repleta de corpos mortos, a onipotência da não-morte é a sensação predominante. A carniçaria é filha de uma forma civilizacional dominada pela sensação de não-morte. Esse domínio leva à constituição de um inimigo completamente outro, desumanizado, desfigurado por completo, sem rosto simpático, mas com rosto. E para combatê-lo empurra ao aparecimento do herói sem medo da mortev .

Se o Saci é uma resposta à carniçaria, e é surpreendente que os diagnósticos de Freud e Lobato à experiência da guerra sejam tão semelhantes - a não ser por um compreensível maior pessimismo mostrado por Freud -, cabe pensar o lugar do Saci na forma civilização, que, como visto, encerra tanto crenças destrutivas, quanto conservadoras e construtivas. O lugar do Saci é aquele da crueldade indecidida. Se a guerra decide, o Saci incide. A crueldade da guerra não é ambivalente de nenhuma forma, ainda que a inimizade possa "trocar de lado", no campo da sensação de nãomorte, toda degola é definitiva em seus termos. O Saci é divertido em sua crueldade, mas não deixa de ser terrível, nem mesmo na capacidade de fazer rir. Não é posto duvidar da maldade do Saci, ou de que seus objetivos não têm finalidade outra que não a perversidade. O mal do Saci não se banaliza e nem se soterra, ele sempre se 
mostra tal como é, nas coisas tal como elas são. Não existe um Saci justo, como haveria uma vontade de guerra justa, o Saci nunca tem grandes bons propósitos, ele possui uma infinidade de pequenos maus propósitos.

Assim, muito embora haja o sistema de crença que permita a existência do Saci, tal como existe o sistema de crença da carniçaria, não podemos dizer que o Saci seja ele mesmo, de todo, uma crença, sendo muito mais uma ilusão.

As perguntas são: (1) Pode uma crença ser comparada a uma ilusão? (2) Teria essa comparação algum efeito na mudança da crença? (3) Pode-se em alguma instância preferir a ilusão à crença?

Pois é isso o que Lobato nos oferece: - o Saci enquanto oposição à carniçaria. Mas como podemos explicar o impasse de que escolhemos a crença à ficção, mas o Saci à guerra? Pois a guerra produz sensação de verdade, posto ser crença, e o Saci, no máximo, provoca sensação de crença, posto ser ilusão. Ainda nesse ensaio de 1915, Freud comenta do perigo e da necessidade da ilusão. O problema geral exposto pelo vienense pode ser mostrado nas seguintes cores: a civilização é dotada de um gérmen de inaceitabilidade. Ainda que por razões de sobrevivência, e cultura, ela seja boa, admiti-la é possível apenas mediante o soterramento da ilusão, amplamente promovido.

Já se tornou quase senso comum dizer que sem ilusão não há civilização, mas o problema é mais profundo, sem ilusão não há aceitabilidade da civilização - o que não significa que ela não possa se impor, a despeito dos soterramentos -, porque não nos tornaremos monogâmicos sem a garantia do amor, sem a evidência de que em algum momento será interrompido o desamparo que nos constitui etc. E no espectro da ilusão que permite a admissão está contida a expressiva probabilidade de que ficaremos sem amor e sem corpo. Não é que não queiramos a civilização - pode ser que a ela possamos aderir até mesmo quando friamente cruel -, mas que não podemos a ela aceitar, sem alguma ilusão, nem que seja aquela concernente à preservação da nossa integridade. Alguma mefistofelia deve existir, ela precisa nos prometer algo, ainda que saibamos que ela não pretende entregar.

Não se pode preferir a ilusão à crença, mas sem ilusão não há crença. Até mesmo a civilização fria é uma crença de civilização fria. Aí está o dilema por Lobato posto, a civilização ou se esforça para ter alguma ilusão concernente ao mal, de modo a tê-lo sempre descontrolado e miúdo, e, então, bem tê-lo, ou não terá outra coisa senão a carniçaria dos homens sem medo.

O mal da guerra - e chamá-la sempre de carniçaria é justificável, uma vez que não mais temos cosmologias ou religião, no máximo, ainda, pequenos delírios racionalistas, para fazê-la bela - não surpreende, porque um "mal", mas porque se dá onde não deveria haver mal, mas apenas desvios civilizacionais. A civilização ao se pretender interruptora dos pequenos males, torna-se morada, não da ilusão metafórica do mal, ou de suas pequenas ofensas, mas do mal social, não percebido enquanto tal, mas com sombra transitória.

Contudo, a grande civilização, uma vez iniciada a carniçaria, não pode dela escapar. Lobato não se propõe a resolver o problema, a guerra parece se amenizar apenas por esgotamento e (des)fôlego, mas resolve explorar o mal pequeno, aquele de uma pequena civilização. Se pudéssemos atribuir alguma arrogância às pretensões de Lobato, denominaríamos essa pequena civilização, de uma civilização outra. Nela o mal social não é jamais controlado, existe uma incompletude nas luzes, uma espécie 
de penumbra, a civilização outra é penumbrínica, existe nela uma forte presença da imaginação do mal. Não há romancistas nessa civilização outra, mas contadores.

Na civilização de direito, por outro lado, como o mal se faz sempre evidente (e por isso pode ser banalizado), por sua grandeza eloqüente, e sua eficiência em controlá-lo, não há efetiva barbarização dos inimigos por meio da imaginação fabulativa. Apenas homens de carne e osso são mortos, nunca seus rostos imaginados. Essa é a civilização avó dos crematórios. Assim, segundo Lobato, o Saci é a ilusão do homem pequeno, de uma civilização outra - na qual a densidade das imagens esconde o rosto, mas não o desfigura -, mas a sua crença não é no futuro, mas na morte.

O homem miúdo, o Jeca, não é um Grego de nenhuma forma, pois ele vê a quase-morte em todas as sombras, ele, como Barthes, não tem outro medo senão o medo da morte, ele é incapaz de temer a um grande mal, de modo a poder se perder do medo da morte, e não é que seja incapaz de bravuras, mas é incapaz de não ver nas sombras a extinção de si mesmo. Ele não consegue temer um grande mal, porque está perdido na diaphonia dos pequenos. Se a ele é vedado o grande medo ao grande mal, são-lhe abertas as portas do vislumbramento das infinitas pequenas perversidades. A guerra não se fixa a esse homem de uma civilização menor, muito embora ele lute, como fez em Canudos, e nenhum rosto é visto com perfeição, o mal e o homem se parecem, este é um homem de circunstâncias ${ }^{\mathrm{vi}}$.

\section{A figurabilidade do rosto do Saci}

Como se pode perceber o Saci, como também ao Jeca, faz parte da estratégia lobatiana de instituir para si uma metafísica política dos personagens. Esta opera tanto de modo trivial, os personagens falam pelo autor, quanto de modo suplementar, os personagens falam pelos que não têm voz. Mas essas duas funções dramatúrgicas dos personagens conceituais, são, por assim dizer, aquilo que possuem de mais fraco. Pois são inexoráveis características da grande política, nisso que por agora é visto como a identificação de uma civilização menor. Essas funções dramatúrgicas acabam por dizer respeito, ainda que Lobato não o veja e não goste dessa prática quando a vê, a certa dimensão representativa da imaginação pública, segundo a qual a ninguém é possível ser concedida atenção como se se falasse em nome próprio. Porque todo enunciado acaba por ser tido como passível de remetimento à biografia ou ao grupo do qual se desprende.

Ainda que essa presença dramatúrgica seja intrínseca a qualquer linguagem, pode-se dizer que Lobato fortemente a assume, mesmo sem querer, e esse é o lado mais fraco de sua obra. Contudo, e esse é o ponto forte da obra, o que nos leva a considerar a necessidade política de uma metafísica dos personagens, existe a possibilidade da ênfase no componente íntimo da enunciação. Isso significa que os personagens, ao possuírem intimidade, circunstâncias enunciativas, pensam para além de suas características de personalidade. O bom personagem é como o homem virtuoso, o seu enunciado é maior do que si mesmo. Os personagens são metafísicos, porque de um modo artificial se colocam em suas circunstâncias a resolver problemas históricos perenes. Mas não se pode comparar, completamente, um homem virtuoso ao bom personagem, pois só o primeiro recebe os efeitos colaterais da experiência em primeira pessoa.

Não se pode dizer que os personagens de Lobato sejam completamente conceituais, porque a enunciação mantém sempre a marca da circunstância em seu conteúdo, o que faz com que ela esclareça a natureza humana e sua condição, apenas de modo incidental. Todavia, cabe apelar a uma natureza semi-conceitual, que não pensa a natureza, mas que pensa algo como uma condição brasileira, histórica em sua 
representação, mas de generalidade tal que os efeitos de minoração da expressividade do enunciado se tornam irrelevantes, por pelo mais uns cem anos.

Para colocar seu personagem para funcionar, Lobato opera com o que Emília denominou de Chave do Tamanho, em romance de mesmo nome de 1942. Depois de assistir a um pôr-do-sol de trombeta, aquele que faz com que qualquer predicação pareça bobagem, em virtude da capacidade de reunir "todos os vermelhos e ouros do mundo", Emília aventa que alguns modos de dizer são pequenas mentiras, e logo é

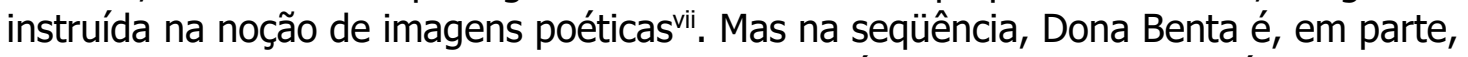
desmentida pelos acontecimentos, e a imagem poética se torna uma espécie de relativização de densas imagens literais.

Pedrinho traz a notícia: "- Novo bombardeio de Londres, vovó. Centenas de aviões voaram sobre a cidade. Um colapso de bombas. Quarteirões inteiros destruídos. Inúmeros incêndios. Mortos à beçaviii'. Ao que Dona Benta é tomada pela sensação de literalidade: "- Vem-me vontade de morrerix". Emília, sem muito respeito, aproveita-se do reconhecimento da literalidade, tomando-o como o avesso das pequenas mentiras: "Alguém abriu a chave da guerra. É preciso outro alguém a feche. Mas onde fica a chave da guerrax?". Pois bem, como todo filósofo da história bem sabe, a casa das chaves, onde as regularidades do mundo podem ser desligadas, só pode estar num único lugar, e para lá Emília vai (com a ajuda de um pó mágico), o Fim do Mundớ.

A boneca de pano se vê numa sala repleta de chaves e percebe que o Fim do Mundo não Ihe ajudará a descobrir a chave da guerra. Por essa razão resolve utilizar o "método experimental" para "ir mexendo nas chaves, uma a uma, até encontrar a da guerra". Procurando a chave da guerra, ela encontra a chave do tamanho:

\begin{abstract}
Se todas as criaturas ficaram pequeninas como eu fiquei, então o mundo inteiro deve estar na maior atrapalhação e com as cabeças tão transtornadas quanto a minha. Mas a guerra acabou! Ah, isso acabou! Pequeninos como eu, os homens não podiam mais matar-se uns aos outros, nem lidar com aquelas terríveis armas de aço. 0 mais que poderão fazer é cutucar-se com alfinetes ou espinho. Já é uma grande coisa...
\end{abstract}

"Ora, a mudança do tamanho da humanidade vinha tornar as idéias tão inúteis como um tostão furadoxii". O operador político da chave do tamanho realiza uma espécie de olho maquiaveliano, pois torna toda a natureza humana pequenina, mas mantém o olho epistemológico com a mesma capacidade de antes, o que obriga a um esforço de singularização para ver o objeto, vê-lo de perto significa o vislumbramento dos detalhes, ao mesmo tempo em que também facilita algo como uma topologia estrutural. Mas o operador chave do tamanho faz mais do que isso, ele cria uma relação de espanto entre os sujeitos e suas práticas, dando-nos oportunidade de ver o reaprendizado do que se é, ao passo que permite uma chance de dúvida acerca dos antigos hábitos.

O operador chave do tamanho, não concerne, propriamente, a uma suspensão do juízo, nem ao modo dos céticos gregos, nem ao modo do velho Husserl, mas consiste numa desorganização do juízo, trata-se de um exercício ativo de poder, sob circunstância de carniçaria, confundir a manualidade, diante de seus artefactos. A ação do operador diz respeito a um desafio saciesco, como quem diz: - Tente atirar agora que suas armas são demais pesadas para a sua força. $O$ operador torna em evidência física o que já é uma conjectura valorativa. A diminuição física, pela imaginação, concerne a um experimento moral. Se certa proporção habitual na relação entre os homens e seus artefactos, conduz à admissibilidade da concentração dos males numa 
única figura soberana, e o exercício da manualidade mortífera, que é incapaz de conceber a própria morte, com o tamanho reduzido, a natureza humana resta com a morte em suas próprias mãos, e, e essa é a crença que permite a chave do tamanho, 0 reajuste momentâneo das proporções, ao interromper imaginativamente o hábito, criaria alguma sorte de vertigem, não com relação ao tamanho das armas, mas em função à dimensão tola da promessa reativa à concentração dos modos numa ficção soberana.

Ainda que o texto sobre a chave do tamanho seja posterior ao Inquérito do Saci, esse pressupõe aquele. Mas como? Ora, de uma forma bastante semelhante ao modo pelo qual o ensaio de Freud sobre a guerra pressupõe o Mal-Estarxiii. Lobato opera com a noção de chave do tamanho já no Inquérito e a ela só dará forma final do texto d'A Chave do Tamanho. Mas como ele faz? Antes de tudo ele tem uma preocupação pictórica com o personagem, que pode ser depreendida da pergunta, como podemos representar o Saci? - Sabemos que representá-lo é um dever, pois fazê-lo é forçar um conjunto de circunstâncias oponentes à carniçaria européia ${ }^{\text {xiv }}$.

Novamente há que se falar em indutivismo, o Saci, para ser representado, precisa ser visto em movimento, no fluxo pictórico de suas representações, as cores em movimento, no ritmo mesmo de suas fugas, a figurabilidade do Saci admite sempre um rosto em deformação, pela rapidez de seus deslocamentos. Dessa forma, tornamonos, pelo operador, bastante pequenos, para que o Saci se torne o objeto pictórico a se tentar fixar em movimento, pequenos como Emília perdida em suas roupaslabirinto, uma vez se tendo feito reduzir. Ou seja, vítimas, nós e Emília, da reductio: uma espécie de alienação ativa que nos faz alienar o mundo, para ver o mundo condição da inscrição do objeto Saciv .

Ao medo concentrado, das soberanias carniceiras, opôs-se o medo dispositivo, do espaço político de pequenos medos. A política tem poucos elementos para pensar os pequenos medos. A crueldade espraiada, tradicionalmente compreendida, é menos política do que a concentrada. Mas não me parece que Lobato proponha, com o Saci, um espaço menos político, ou menos político do que o europeu, nem mesmo a figura do Jeca Tatu - aquele que não vota e não paga imposto -, parece-nos concernente à proposição de algo pouco político.

Por certo, trata-se de uma política outra, preocupada com a sua composição, enquanto experiência, em algum lugar presa, entre a morte do império e o nascimento da república, submetida ao medo soberano e à morte concentradora, como em Canudos, distinta da carniçaria, disforme como a figurabilidade do Saci, ainda que sem nome, sobretudo, política outra. Nesse sentido, o modelo hobbesiano, do medo, hipostasiado, à morte violenta, não parece ser adequado para pensar no medo que cria o Saci. Donde se pode depreender um divertido axioma: Se há Leviathan, não há Saci. Não se trata apenas de distintas intensidades do medo, mas de modos distintos do medo. Aquele com muitos medos cotidianos é vedado ter um medo só. Na mesma proporção, aquele que se ocupa com a espectralidade difusa da morte, na vida de todo o dia, é vedada a inautenticidade do medo da morte direcionada ao Estado ou a Lei. Contudo, na cotidianidade do medo e na espectralidade difusa, são-nos vedados os heróis. O medo na circunstância Saci é mais bem descrito por Montaigne, do que por Hobbes ou Heidegger.

A treva gera o medo; o medo gera deus e o diabo, e gera ao pé destes a legião inteira da boêmia infernal - deusinhos e demoninhos menores [...] anões subterrâneos, bleu-devils escoceses [...] e sacis [...] O medinho contagioso abrir-lhe-á todas as válvulas da compreensão. E saberá pela boca 
ingenuamente crédula do Jeca Tatu que tempera a viola que o Saci é um molecote daninho, cabrinha malvado, amigo de montar em pêlo nos 'alimais' soltos no pasto e sugar-lhes o sangue enquanto os pobres bichos se exaurem em correria desapoderada, às tontas, loucos de pavorxvi.

Se o mal soberano nos coloca diante de um grande demônio que nos oferece segurança em troca de nossa alma, o pequeno mal concerne a um demoninhoxvii. Ambos os contratos são igualmente mefistofélicos, entregar a alma não significa ter aquilo pelo que se renunciou. Mas no caso do demoninho, existe a possibilidade de encarcerá-lo, ouvi-lo contar as suas perversidades, para daí tentar um pacto um pouco melhor. Trata-se de um mefistofelismo rebus sic stantibus e não pacta sunt servanda. Isso porque o contrato pode ser refeito, pois, de alguma forma, o pequeno demônio gosta de contar, enquanto o soberano precisa esconder, até mesmo mudando a natureza do segredo político, e gosta de contar, sobretudo, de modo sádico, para quem ao gostar de ouvir, ofende-se ao ouvir. O que nos protege do pequeno demônio é que ele é apaixonado pela ambivalência, e nela se exibe; enquanto que o demônio soberano, na ambivalência, domina. Assim, o pequeno demônio se deixa seduzir pela natureza humana. Dizendo ao modo dos céticos: ele consiste numa dessas inconscientes invenções que se seduzem pelo rosto ambivalente que as cria. Ao passo que o demônio soberano é atraído pelo ambivalente rosto da natureza humana para desfigurá-lo enquanto rosto que sente dor. A natureza humana é uma arapuca natural ao Saci, mas uma presa frágil do demônio soberano. O Saci, como veremos, desfiguranos o rosto para obter atenção, e, nela, poder se fazer mimesis conosco, explorar nossa ambivalência. Com o demônio soberano, deve-se perscrutar a própria natureza humana, para, na geografia das ambivalências, estabelecer modos de disciplina para a crueldade. À crueldade do Saci, basta Ihe dar atenção e deixá-lo surgir um pouco em nós a sua maldade, na adesão existente no rosto que presta atenção.

Não devemos deixar de notar que a carniçaria européia muda a natureza do segredo político, como começamos a indicar acima, ela faz da morte um fenômeno incontável. Ainda que, antes da carniçaria, a civilização concentre em si o medo da morte, fazendo do homem, porque morada do infinito, o animal inautêntico, incapaz de pensar a própria morte, ao pensar a morte do outro, os segredos do demônio soberano são todos de natureza discursiva, não podemos saber, em função do pacto, entregamos a alma, mas se víssemos, escrito em uma carta roubada, entenderíamos. Mas por alguma razão a incontabilidade dos corpos, tornou inadmissível o segredo, mas nas letras miúdas estava comunicado que em caso de carniçaria civilizada, a natureza do segredo se alteraria e se faria técnica, numérica, formal etc. Por alguma razão os incontáveis corpos fizeram o segredo discursivo insuportável, pois até a segurança soberana se mostrou pouco segura, e se nos foi franqueado uma plena revelação, um segredo soberano plenamente aberto, público e não discursivo, a ele não podemos compreender. Uma carta roubada não teria qualquer importância. Interessante perceber, ao que nos parece, que o Saci, ao contrário da soberania, não sabe fazer contas, e não pretende aprender.

\section{Saci: rosto, voz e crueldade}

Precisamos renunciar àquela parte da crença que num pacto soberano integral, afasta-nos por completo da necessidade pensarmos a crueldade, tanto no que concerne à crueldade soberana, cuja física é de encobrir a si e a sua própria ambivalência, quanto à atração que a crueldade exerce na descoberta do Outro, para podemos sustentar a ilusão Saci. 
Pode ser que a renúncia necessária para termos a condição pictórica do Saci seja desprazerosa, tal como a ilusão do amor e da morte, uma vez que é profundamente triste a percepção da mefistofelia do pacto a que temos que nos iludir, uma vez que o Saci, como nos diz Lobato, parece-nos uma tolice. Mas o argumento da necessidade é moral, antes de lidar com uma pequena maldade espraiada, do que não conseguir ver a crueldade encoberta por uma grande moral abstrata ou burocrática. Precisamos imergir nas circunstâncias das pequenas crueldades, para vermos as grandes e combatê-las.

Orientamos a nossa fixação plástica do Saci [ou montagem] de acordo com os seguintes princípios: 1) rosto, 2) voz, 3) ferida e 4) morte ou tortura. A tortura de animais será compreendida como ferida ao homem, posto que o Saci se ocupa dos animais com algum traço doméstico, para atingir o rosto humano e ser seduzido por ele. Assim, acompanhamos o Inquérito do Saci de Lobato, um tanto quanto imersos na ilusão, ou seja, desejamos ver o seu rosto, ainda que seja impossível, desejamos fazer dessa experiência elemento para fixação pictórica de nosso mundo e admitimos o conteúdo onírico presente em toda linguagem ${ }^{\text {xviii }}$.

\section{Da rostidade}

p. 45. "Ele era um negrinho muito magro, muito esperto, de uma perna só, do tamanho de um menino de 12 anos, muito feio, banguela, olhos vivos, rindo sempre um riso velhaco de corretor de praça, carapinha grande, a saltar e a saltar e a fazer peraltagens ruins".

p. 53 "co os óio que nem brasa, dando muito risada".

p. 57 "é Saci barrigudinho moleque pigmeu que assalta, a desoras, o incauto viandante nas estradas solitárias do sertão pedindo-Ihe fumo e fogo e mostrando-lhe dois olhinhos muito brilhantes e os dentinhos pontiagudos; diz o caboclo convencido: ai daquele que recusar satisfazê-lo".

p. 61-62 "não tem pêlo no corpo e nem à cabeça; dos olhinhos vivos como os da cobra e vermelhos como os de um rato branco".

p. 62 "o nariz, boca e dentes igualam-se aos dos pretos americanos".

p. 71 "- Pequeno, negro azeviche, os olhos grandes que parecem saltar chispas, tal é o seu brilho e a ligeireza com que se movem, o nariz é comprido e arrebitado; a boca parece mais uma caverna de fundo vermelho, que ao se abrir mostra duas fileiras de dentes horríveis, cortantes como navalhas; os cabelos e o bigode parecem fios de arame, tal é a sua dureza".

p. 75 "O Saci bota fogo pelos olhos, como a mula-sem-cabeça bota fumaça pelas ventas".

p. 78 "de beiços vermelhos como o açafrão".

p. 82 "- cara de macaco, muito delambido -, filho do diabo".

p. 85 "tinha a forma humana".

p. 93 "cabeça oval e olhos vivos".

p. 105 "nariz adunco, barbinha de bode preto".

p. 111 "rindo como um perdido, mostrando os dentes alvos e as gengivas roxas". "Quando ria, saía-Ihe fogo pelas narinas, e os olhos cintilavam-Ihe como aquelas brasas ainda não extintas". "E lançando-lhe fumaça nos olhos". 


\section{p. 116 "cospe fogo de sua boca".}

p. 123 "fazendo caretas".

p. 124 "mostrando a língua rubra e deitando chispas pela boca".

p. 128 "beiços e olhos vermelhos com brasas, trazendo na cabeça uma carapuça escarlate. Naquela posição o negrinho ria a mais não poder, e ria de um rizinho muito agudo que penetrava os ouvido".

p. 145 "c'os óio aceso".

p. 153 "beiços e olhos vermelhos como pitanga, [...] tem testa de macaco".

p. 161 "de cara verrugosa [...] era filho do diabo. Sendo muito mau foi expulso do inferno e condenado a viver na Terra, a assombrar todo mundo".p

p. 169 "a barba com a de um bode, [...] os olhos grandes e vermelhos, boca aberta, sempre num sorriso sarcástico e mau, uma carapuça vermelha à cabeça grande e disforme, em formato duma melancia comprida, dentes alvos e pontiagudos".

p. 186 "olhos vivos com a íris pigmentada de preto e a esclerótica luminosa, dentes alvos sobre gengivas rubras através de lábios grossos e vermelhos".

p. 190 "vejo minha garupa um negrinho de beiços muito vermelhos e risonhos".

p. 195 "A arcada dentária saliente e munida de dentes alvos e aguçados. Rosto fino, comprido e encovado. Fisionomia alegre, prazenteira e soltando continuamente um riso sibilado e fino".

p. 208 "com um palmo de cara grossa e felpuda, rindo-se como cachorro louco".

p. 212 "de um olho só no meio da testa e usava uma carapuça vermelha".

p. 223 "os olhinhos brancos e ativos a luzirem, irrequietos e maliciosos no nanquim tapado da cara redonda; lábios rubros e grossos, entreabertos, deixando ver a dentadura muito alva e de serra, como se fosse limada".

p. 228 "risada vermeia de fogo".

p. 236 "toda a multidão amarela dos grandes dentes pontiagudos; orelhas enormes, à semelhança de morcegos". "E os olhos? Grandes, redondos, esbugalhados, abrindo duas vivas chagas de fosforescência sangüínea na escuridão".

p. 247 "Como Demócrito, nunca chora".

p. 272 "ria-se gostosamente mostrando uma dentadura admirável; o cabelo encarapinhado não era vermelho com a princípio me pareceu, mas cor de ouro".

p. 299 "de nariz esborrachado".

p.300-301 "A cara é quadrada de preto velho, que já ultrapassou os cem janeiros; no meio do vasto carão, lá está implantado o nariz formidável que, de tão chato, até parece ter sido amassado por uma valente punhada. Os olhos são vermelhos com coágulos de sangue e tão vivamente rolam dentro das órbitas que qualquer esculápio aí veria o fenômeno do nistagmo. Das orelhas, nem é bom falar; sobre serem enormes e acabanadas estão situadas em alturas diferentes. Quanto à boca, que limitam lábios grossos, é um pouco torta; isto, aliás, não é de estranhar, porque o Saci, que é fumante incorrigível, sempre que pode, usa e abusa do cachimbo... alheio. A cara enrugada e glabra é animada por uma expressão feroz - feita de maldade e ironia".

p. 321 "que os seus olhos se haviam transformado em brasas". 
p. 331 "Tem também um oio só, mais maió do que uma laranja-baiana, i o tár inxerga mais do que coruja; tem nariz, boca; barba iguar que do bodi; [...] num tem cabelo na cabeça, mas tem dois chifre cumprido, duas oreia e seti ispinho; a cara é mais preta que jaboticaba. Homi qué sabe vancê duma coisa? Eu prefiro vê mir capeta do que um Saci!".

\section{Das locuções}

p. 45 "Saci, saterê nhangu!".

p. 46 "Sa... ci!".

p. 61 "assobio agudíssimo [...] Saci-perê-sem-fim".

p. 62 "Seu Joaquim!... Seu Joaquim!".

p. 62 "Um Saci, firme na porta, arreganhado, desdenhando da minha solicitude, pachola, teve para comigo esta frase: - 'Boa Noite! Dona Evarista! '. Desmaiada, caí e, até hoje, não posso me recordar dessa figura exótica, sem um nojo, sem um asco, pois que ainda fede a enxofre".

p. 63 "Nhá Mônica! Amanhã me faça um pastel grande, grande, assim".

p. 96 "até as duas horas assobia 'saci-pererê', num diapasão tão forte que até abala as casas e faz estremecer o solo".

p. 123 "saci-saci-saci".

p. 140 "-Meu avô, seu fumo é muito fraco, mas tem bom gosto - e o Saci, no mesmo instante, 'suverteu' no ar".

p. 146 "sa... ci... sa... ci...".

p. 170 "o Saci disse-Ihe adocicando muito a voz, como se fora uma namorada: - Seu

Chico, você só passará aqui se me der fogo e fumo bom e levar-me à garupa até lá adiante, sem parar; porém, perto do rancho que ali tem... [...] O Seu Chico estarrecido fez o sinal-da-cruz, o Saci fugiu gritando: - Você há de ver... Negro ruim... [...] [T]eve a infelicidade de se encontrar novamente com o Saperê... Aí sofreu horrivelmente, apanhou bons cascudos, sob risadas gostosas e gritos contentes: - Não disse?! Faça mais aquilo? Faça? Tome, negro ruim... Tome...".

p. 195 "Semelhante à passagem do vento entre as folhas das árvores: si... i... i... i... i si... i... i... i si... i... i... i... i".

p. 326 "há que quando ele assobia perto é sinal de estar longe e quando assobia longe é sinal de estar perto".

\section{Das feridas}

p. 42 "de repente parecia-me que um saci vinha pulando atrás de mim; eu queria correr; parecia-me entretanto que ele dizia: - se correres é pior! - Eu obedecia, mas apressava o passo; ele imitava-me; eu temia por ser segurada, apressava mais; ele fazia o mesmo, eu perdia a tramontana e quando não gritava a plenos pulmões, corria cegamente e supunha que ele já ia alcançar-me; já estava perto... estendia a mão...".

p. 43 "Pela manhã o animal ou os animais eram encontrados exaustos, a crina toda embaraçada, às vezes machucados...".

p. 49 "e com uma ferida no pescoço vertendo sangue". "e sugar-lhe o sangue".

p. 63 "sova a cachorrada que o acua, deixando-a em mísero estado". 
p. 78 "Ao passar a mata virgem, ponto divisório das duas fazendas, o moleque pulouIhe na garupa e cruzou-Ihe as mãos no "imbigo". O cavalo bufou e disparou. Ao abrir a primeira porteira olhou para trás: o 'capeta' estava firme e gritou: - 'Toca depressa'. Daí veio aos berros até a casa. E o fato é que o cavalo estava extenuado, escorrendo suor como uma bica d'água".

p. 82 "Pois é ele que anda em procura dos minino que vai caçá passarinho e escangaiá os ninho, pra mór de enfiá eles num buraco muito fundo e judiá deles. E quando ele encontra muié, meu fio, faiz um estrago desgramado".

p. 86 "Quando me aproximei da ponte um pequeno me contou que o Saci tinha atacado o acendedor de lampiões e tomado a escada, levando-a para debaixo da ponte. O homem por muita felicidade tinha conseguido escapar!".

p. 96 "distribui aos animais valentes surras de chicote".

p. 116 "Ai de quem não o atendia! Deixava-o com uma só pancada estendido no solo".

p. 140 "Tio Cosme, quando recebeu a baforada na cara, caiu para um lado e só foi encontrado no outro dia pelos camaradas da fazenda, ainda desacordado".

p. 154 "O Saci pilhava os negrinhos a sós, ia lá sová-los. Os negrinhos berravam, as negras diziam: - Saci já tá judiando dos negrinhos".

p. 162 "o Saci depois de voltar das suas viagens sangra o cavalo para não ficar aguado".

p. 173 "o Saci vai espalhar fogo pelos cafezais, mata e canavial".

p. 182 "Entretanto os patrões encontraram: na verdura uns pequenos caramujos nojentos, melosos; no arroz uma mosca; no feijão uma barata; e na canjica o picumã; em contraste este com a cor da canjica, sendo aquele um corpo estranho preto que só um cego deixaria passar. E a cozinheira não viu! Esta entra em desespero ante os patrões já exasperados, com o apetite estragado de tantas porcarias! A cozinheira volta logo o pensamento para o Saci diabólico que talvez ali esteja num canto da cozinha, invisível, em gargalhadas!".

p. 187 "Neste comemos fora despertada por uma solene bofetada que a debruçara sobre a rede! [...] E a humilde Isaura, prestes, contou que também vira o Saci, que por sinal [...] correu atrás dela até a cozinha e lhe segredou que batera em sinhara para que não dormisse mais na reza".

p. 195 "cospe nas panelas quando a cozinheira é preta. [...] Aproveita os dias de vento para atirar terra nos olhos humanos".

p. 199-200 "É fama por aqui entre gente da roça que a máquina de café de certo fazendeiro - um jovem sportsman, que às vezes pilotava a sua 'Fiat' pelo 'corso' da avenida - fora incendiada por... um Saci!".

p. 220 "O negrinho vai primeiramente buscar os arreios, monta os animais, trança-Ihes a crina e alguns, com as correrias obrigadas pelo Saci, morreram".

p. 225 "Os bois, a uma, despedaçando cangas, arrastando tiradeiras e partindo chifradeiras, abalaram, aos arrancos, tombando o carro e espalhando a sacaria [...]. 0 fazendeiro foi arremessado a distância, meio desacordado. O carreteiro, esse, envolvido no alumínio de peças partidas, teve uma coxa luxada e só voltou a si horas depois".

p. 238 "um saci atravessa-se-Ihe diante, salta-lhe aos ombros, põe-se-lhe a trançar apertadamente a cabeleira que usava grande. Tratava aquele corpo [...] como a um 
[...] animal. [...] Baldadamente lutava o mísero, sentindo o couro cabeludo repuxado em milhões de pontos que Ih'o crivavam de milhões de dores agudas, num desordenado desespero, por sacudir de si o ser demoníaco, que, certo, prontas as tranças, havia de o impedir ruas afora, numa hipogrífica disparada de morte. [...] Em apuros tais, que alma de bronze não vergaria genuflexa? [...] $\mathrm{E}$, sob o testemunho dos infinitos olhos nictantes dos céus - o ateu baqueou de joelho e... forjou uma oração".

p. 266 "Saci deu uma bordoada na negra e negra caiu".

p. 302 "Atordoado, sem saber o que fazia, atirei a minha enxada sobre o 'bicho', que soltou uma gargalhada e se atirou sobre mim. Não me mexi do lugar, mas não vi mais nada, porque... eu sumi".

p. 303 "aproveitando-se de um momento de descuido do homem, atufou-se na água, poluindo-a".

p. 357-358 "Um saci agarrou o Cara-cará [sobrenome do senhor Quim, folheiro, doente de um papo 'sui generis'] pelas costas e outro deu-lhe um puxão com tamanha força no papo que este se despregou do pescoço e, escapando das mãos do saci, ficou dependurado num galho da figueira. [...] [em resposta a tentativa do senhor Paneleiro a também se livrar de seu papo] - Vamos pregar-Ihe mais um papo? [disse um dos sacis] [...] E imediatamente um saci subiu à figueira, tirou o papo do Quim Cará-cará e... - paff!, pregou-o no toutiço do Zeca Paneleiro com tal violência que o fez focinhar".

\section{Da morte}

p. 166 "Tempos depois, porém, ao passarem pelo local, onde haviam enterrado a cabecinha peçonhenta, a mulherzinha insiste até conseguir que o marido a desenterrasse e a abrisse para verem o que tinha dentro. Foi um deus-nos-acuda. Não se sabe como podia ter ali tanto marimbondo venenoso! O casal ficou com o corpo estraçalhado e por fim os olhos foram furados".

p. 304 "O cavaleiro seguia despreocupadamente quando, de súbito, sentiu que alguém Ihe saltara às costas, fixando-o com um braço ao arreio e arrebatando-lhe as rédeas do animal. [...] O burrinho, tomado de pavor, arrancou numa corrida doida e, como um furacão, quebrando galhos, fustigado pelos ramos dos arbustos e guiado pelo Saci, voava, às cegas, na direção do abismo. [...] Continuava, já durante alguns minutos, aquele galope fantástico, levando às costas a dupla carga; de repente, faltou-lhe o terreno e a cavalgadura e o cavalheiro precipitaram-se no vácuo. [...] Seguiu-se o baque surdo dos dois corpos no fundo do precipício, enquanto em cima, à beira do despenhadeiro, o Saci, como louco, aos pinchos, virando cambalhotas, cantara num gargalhar uníssono o seu hino de vitória".

p. 319 "é costume o Saci matar os que o ofendem a cócegas ou a pancada."

\section{Da tortura de entidades metafísicas correlatas ${ }^{x i x}$}

p. 232 "E lá, então, encaminhou um fiozinho d'água de modo que gotejasse lentamente bem no meio da testa da Cuca. - Basta isso - disse [o Saci]. - No começo ela nem sente; mas com a continuação a dor vai ficando tamanha que há de dar-se por vencida".

p. 233 "Os pingos começaram a cair. Os cem primeiros nenhuma impressão fizeram na bruxa, cujo sono parecia dos mais gostosos. Daí por diante já esse sono não pareceu mais tão calmo. Começou a fazer caretas, como se estivesse sonhando algum sonho horrível. Por fim abriu um olho e depois o outro. [...] Por vários minutos permaneceu 
apatetada, vendo diante de si aquelas duas criaturas de mãos na cintura, a olharem para ela sem dizer coisa nenhuma. Depois a sua inteligência foi acordando e notou o pingo a lhe cair na testa. Quis mudar de posição. Não pôde. Só nesse momento viu que estava amarradinha como se fosse um carretel e condenada à mais absoluta imobilidade".

p. 235 "A dor que a queda de um pingo atrás do outro já estava causando nos miolos da bruxa começava a crescer ponto por ponto. Cada novo pingo era um ponto a mais de dor. Naquele andar ela não suportaria o suplício nem um mês, [...] há de morrer no maior suplício que existe".

\section{Conclusão}

Antonio Candido, no primeiro prefácio da Formação da Literatura Brasileira, escreve sobre a pobreza e a fraqueza da nossa literatura, quando comparada com outras. Mas, por alento, ele nos propõe um sentimento teórico de suplência. Se não se estudar por aqui, ninguém estudará a literatura brasileira. No campo do pensamento político, a teoria da suplência de Candido é assumida quase que inconscientemente. Cabe compensar a menoridade de autores brasileiros com o sentimento de estabelecimento de cânone. Ou, quando não, de historiografia de objeto desprezado ${ }^{\mathrm{xx}}$.

Este sentimento foi agrupado na pergunta sobre a existência do pensamento político brasileiro. A tentativa de responder essa pergunta já é em si o maior dos equívocos. Faoro tenta justificá-la distinguindo o ambiente cultural da política, a proliferação prática de seus discursos, da filosofia política. E, nesse contexto, pergunta sobre a existência de uma propriedade brasileira para a tal práxis ${ }^{\mathrm{xxi}}$. Mas nem mesmos as vênias do culturalismo consegue espantar a falsidade do problema.

Ora, pois, há autores e existem problemas. Se o problema é falsificado, deve ser esquecido. Se o autor é inautêntico, também o deve. A afirmação de uma cultura política independente do pensamento filosófico nada mais é do que um álibi para não pensar. A cultura não é tão pequena que não precisa de filosofia e a filosofia não é tão grande que não esteja também na cultura. Até mesmo o trabalho com documentos não existe sem um conceito, e se optarmos pensar por autores, pois bem, deve-se estar na posição enunciativa autoral.

Assim, tanto não é o caso de perguntarmos pela homologia universal de todo pensamento, consistente à maneira da idéia de uma república das letras, como também não é o caso de insistirmos em características culturais da atividade política. 0 pensamento político já começa pensando. Ele não se pergunta sobre o seu pertencimento, mas se inicia numa forte atratividade com relação aos problemas que julga poder resolver.

Esta conclusão serve para dizemos que a presença ou ausência de pensamento político, ou de pensamento político brasileiro, ou pensamento político feito no Brasil etc. é uma falsa questão. A única reflexão unificadora poderia se dar pela língua, não porque haja uma essência comum ao pensamento português, mas porque é um fato de proximidade. Mas não mais do que isso. Não parece ser muito relevante saber a porcentagem das vezes que um problema foi abordado em determinada língua, ainda que seja epistemologicamente possível. Dessa forma, unifica-se uma disciplina pelo seu objeto, o que nos permite falar em problemas brasileiros, e, até mesmo, observar as abordagens de problemas brasileiros em português. Essa generalidade não é filha da suposta universalidade do pensamento político, mas tão somente concerne ao fato de que o pensamento começa pensando, circunscrito, mas à altura do que o fez começar, o problema, e não o expediente. A comparação entre abordagens em 
idiomas diferentes nada mais é do que a contraposição circunstancial de autores, mas nunca de apropriações nacionais da suposta essência do pensamento.

Por essa razão, pensar Lobato e os problemas que Lobato pensou nada mais é do que pensar Lobato e suas questões e fazê-las, ainda que de modo alterado, em minhas questões. Que não são mais minhas do que das experiências as quais pertenço. Há que se concordar que o problema do personagem é exercido pelo taubateano com inigualável intensidade, inclusive, no que concerne à invenção de personagens de agência semi-conceitual a partir de questões bastante brasileiras. 0 caso do inquérito abre as entranhas de um pensar por ele praticado em toda a sua obra, e o fato de resistir ao conceito não faz dele um pensador menor, mas um pensador difícil, apenas demonstra a sua opção por outro tipo de imagem que não a conceitual, que é a imagem literária. Talvez por uma percepção estratégica da especificidade dessa imagem na fabricação de mundos na experiência do Brasil em que viveu. Assim, a estratégia de buscar operadores conceituais em sua obra para crianças, pratica uma forma de desrespeito capaz de atingir apenas aos pensadores.

(Recebido para publicação em janeiro de 2019)

(Reapresentado em março de 2019)

(Aprovado para publicação em abril de 2019)

\section{Cite este artigo}

KIRALY, Cesar, 2019. Lobato e a Metafísica dos Personagens. Revista Estudos Políticos: a publicação semestral do Laboratório de Estudos Hum(e)anos (UFF). Rio de Janeiro, Vol.10 | N.1, pp. 73-96, maio de 2019.

\section{Notas}

1. Monteiro Lobato, O Saci-Pererê: resultado de um inquérito (São Paulo: Globo, 2008). p. 27.

2. Lobato, O Saci-Pererê: resultado de um inquérito. p. 25.

3. —, O Saci-Pererê: resultado de um inquérito. p. 25.

4. —, O Saci-Pererê: resultado de um inquérito. p. 27. A citação do intróito se inicia assim: "Começara mal o ano de 1917. A carniçaria européia, refletia por cá o clarão dos incêndios, os estouros dos obuses, a angústia do gás asfixiante e a selvageria dos modos civilizados de matar em grande. Quem se afrontasse a abrir uma folha sorvia sangue dos telegramas à seção livre. Um engulho. Foi quando surgiu o Saci, e veio com suas diabruras aliviar-nos do pesadelo". 
5. Otto Rank, The Mith of the Birth of the Hero (New York: BiblioBazaar, 2008 [1914]). p.27.

6. Por certo que a batalha entre a carniçaria e os pequenos males é trágica, e, portanto, já está perdida. "Pobre do meu Jeca Tatu, serás suprimido! Negar-te-ão na paz; rebentar-te-ão a dinamite na guerra". Lobato, O Saci-Pererê: resultado de um inquérito. p. 373. Existe uma batalha a ser perdida, e cabe resistir para atrasar a derrota. $O$ tempo da derrota pode ser fundamental. "Pois bem: seguimos o caminho errado. Condenamos o Jeca à morte. Damos-Ihe na cabeça com o rifle na guerra, com o alfabeto e o voto na paz. Jeca, entretanto, resiste. É na paz o que foi em Canudos: um heroísmo silencioso que morre, mas não adere. Jeca só trabalhou para si: nunca virá ao país um conde montado no trabalho dele. Jeca não lê: o binóculo nunca atingirá proporções de telescópio por culpa tele. Jeca não vota: nunca assentarse-á na currul suprema um... (autocensura) pelo peso de um voto seu. Jeca não paga impostos. Resiste ao fisco pelo meio mais eficaz: não acumulando nada que meirinhos possam penhorar. Resiste à cultura, resiste a Havas, resiste ao suelto, resiste ao juiz, ao escrivão, ao sargento de política, à Light, ao cônsul inglês, ao estado de sítio, ao Miroir de la Mode, ao parnasianismo, ao João do Rio, ao Largo do Rosário, a Sanches, ao patriotismo, ao nacionalismo de artigo de fundo, ao telefone, aos Aveugles-nés, às Indústrias Reunidas, à colocação dos pronomes, ao Mappin, a Rosatti". —, O Saci-Pererê: resultado de um inquérito. p. 375.

7. Monteiro Lobato, A Chave do Tamanho (São Paulo: Círculo do Livro, 1984). p. 8-9.

8. Lobato, A Chave do Tamanho. p. 10.

9. —_ A Chave do Tamanho. p. 10. Todavia, apesar de tomada pela alegoria do pôr-do-sol, deve-se fazer justiça à Dona Benta que ensinara a literalidade à Emília: "[N]ossas idéias são filhas da nossa experiência". p. 17.

10. _ A Chave do Tamanho. p. 10-11.

11. — A Chave do Tamanho. p. 11-13. O leitor deve estar pensando no pó de pirlimpinpin, mas não, esse se mostrou fraco para levar ao Fim do Mundo, e como todo filósofo da história, Emília não se contentou com a alucinação naturalista 
do pirlimpinpin e apelou para o delírio do "superpó".

12. — - A Chave do Tamanho. p. 16.

13. — A Chave do Tamanho. p. 17.

14. Devo essa tese da leitura anacrônica dos dois ensaios de Freud citados à sugestão do professor Renato Lessa e apliquei a mesma estratégia à leitura da obra de Lobato.

15. — O Saci-Pererê: resultado de um inquérito. p.35. "[G]rosseira superstição popular, dessas que depõe contra os nossos créditos de civilizados perante as nações estrangeiras". Isso na conta das ironias do Lobato. "Cada qual puxava dos desvãos da memória uma reminiscência quase extinta. Ventilaram-se todas as impressões saciescas, narraram-se os casos sabidos e, palavra vem, palavra vai, nasce a idéia do inquérito". p. 35.

16. — $—$ O Saci-Pererê: resultado de um inquérito. p. 31-32. "No dia essa enfant-terrible das capoeiras for fixado em formas definitivas pelas artes plásticas, o nosso patrimônio artístico ter-se-á enriquecido de algo nuevo". p. 32. "E como a figura do Saci varia de zona a zona, conforme grau de medo que a natureza noturna inspira [...], este fato exige deles uma onerosa investigação dispersiva, caso queiram ser honestos". p. 34. "No entanto, nenhuma tentativa ainda foi feita para fixá-lo na tela ou no barro". p. 34. "Se o barro do Poá de Oliveira Filho não resolve, do ponto de vista estético, a fixação plástica do Saci, culpa mal cabe ao autor". p. 34. "O autor protestou contra o menoscabo do seu talento escultural. 0 articulista não se explicara convenientemente. Queria dizer que se um Rodin houvera lidado o Saci a escultura teria saído um pouco melhor do ponto de vista da técnica. É perdoável esta boa idéia que ele faz do Rodin". p. 34. "Tem culpa o país [...] em que os negociantes se vêem forçados a meter as mãos no barro e ensinar 0 caminho a escultores de profissão".

17. — inquérito. p. 33.

18. — - O Saci-Pererê: resultado de um inquérito. p. 33. "E que em dias de vento ele passa pinoteando nos remoinhos de poeira. $\mathrm{E}$ que nessa ocasião basta lançar no turbilhão um 
rosário de caiapiá para tê-lo cativo a seu serviço com um criadinho invisível. E saberá mil particularidades mais, ouvirá 'causos' de mil diabruras pelos campos, ou dentro de casa [...]. E ficará encantado com [...] [o] pernetinha cuja mania é atazanar a vida do sertanejo com molecagens de todo o gênero, sem entretanto cair em excessos de perversidade".

19. — O Saci-Pererê: resultado de um inquérito. p. 36-37.

20. Monteiro Lobato, O Saci (São Paulo: Círculo do Livro, 1984).

21. Antonio Candido, Formação da Literatura Brasileira (Rio de Janeiro: Edição Itatiaia, 1981).

p. 11. Podemos dizer que o estudo comparativo, de toda forma, apenas acrescenta ao estudo da literatura brasileira e daqueles livros que denominamos integrantes do pensamento político brasileiro. Todavia, a idéia de que a grandeza de uma obra, ou de um conjunto de obras, seja percebida por comparação não é inteiramente verdadeira. Sim, ela é verdadeira, porque podemos perceber algo de maior ao comparar as semelhanças entre dois grandes escritos, como, da mesma forma, pode-se perceber a pequenez de um escrito ao comparálo com um que sabemos importante. Mas não é estranho pensar que algo de grande deva sê-lo por algum conteúdo que não possa ser comparado. A idéia do senso comum de que o brilhantismo habita no que não pode ser percebido em nenhum lugar senão no objeto que o emana, parece ser verdadeira. Mas também não precisamos admitir uma essência do bom pensamento. Parece ser relativamente aceitável que o pensamento possa ser percebido em sua autenticidade, ainda que saibamos que essa é circunscrita e provocada pelas mudanças da passagem do tempo.

22. Raymundo Faoro, "Existe um pensamento político brasileiro?," in A República Inacabada, ed. Editora Globo (São Paulo: 2007). p. 31.

\section{Referências bibliográficas}

Candido, Antonio. Formação Da Literatura Brasileira. Rio de Janeiro: Edição Itatiaia, 1981.

Faoro, Raymundo. "Existe Um Pensamento Político Brasileiro?" In A República Inacabada, edited by Editora Globo. São Paulo, 2007. 
Freud, Sigmund. Considerações Atuais Sobre a Guerra E a Morte. São Paulo: Companhia das Letras, 2010 [1915].

Lobato, Monteiro. A Chave Do Tamanho. São Paulo: Círculo do Livro, 1984.

—. O Saci. São Paulo: Círculo do Livro, 1984.

- O Saci-Pererê: Resultado De Um Inquérito. São Paulo: Globo, 2008.

Rank, Otto. The Mith of the Birth of the Hero. New York: BiblioBazaar, 2008 [1914] 